\title{
VALIDAÇÃO DO MÉTODO DA SELEÇÃO DE GENÓTIPOS DE CANA-DE-AÇÚCAR PARA O ESTADO DO PARANÁ
}

\author{
VALIDATION OF THE SELECTION OF GENOTYPES OF SUGAR-CANE \\ FOR THE STATE OF PARANÁ
}

\author{
José Luis Camargo ZAMBON \\ Orientador: Professor Dr. Luiz DONI FILHO (Departamento de Fitotecnia e Fitossanitarismo - UFPR)
}

\begin{abstract}
RESUMO
Foram conduzidos experimentos com genótipos de cana-de-açúcar das séries RB84, RB85 e RB89, em 17 locais do Estado do Paraná, que pelas características climáticas apresentam uma região apta, com temperatura favorável ao crescimento da cana-de-açúcar e outra com restrições variadas ao cultivo, ao sul do Estado. Os experimentos utilizados são da Fase Experimental (FE) do processo de obtenção de novas variedades do Programa Cana-de-açúcar da RIDESA - PR. Com o objetivo de validar o método usado na avaliação de novos genótipos de canade-açúcar, foram identificados aqueles com bom potencial de produção, determinada a adaptabilidade e estabilidade dos mesmos e comparadas as três séries RB. Para a adaptabilidade e estabilidade usou-se o método de Eberhat $\mathrm{e}$ Russel e a identificação e comparação dos genótipos foi feita por teste de médias, coeficiente de variação entre as médias dos diferentes locais, freqüência de superioridade aos padrões, apresentados histogramas por faixa de freqüência para cada série. Usou-se as características de $\mathrm{TCH}$

(toneladas de colmos de cana-de-açúcar por hectare) e TPH (toneladas de POL por hectare) como indicativo para a escolha dos melhores genótipos. Pelo método usado, é possível a identificação de genótipos superiores nas três séries, A heterogeneidade dos resultados mostra a necessidade da avaliação ser feita no maior número de locais possível. A interação dos genótipos com o ambiente apresenta aumento de produção com a melhoria de ambiente, com magnitude diversa entre eles, pela variação na resposta dos genótipos a esta interação. Quando comparadas as três séries, embora alguns genótipos de séries diferentes tenham os mesmos progenitores, mostram comportamento diferentes e a RB89 foi a que apresentou valores médios de TCH e TPH menores, porém, como as outras séries, esta possui genótipos promissores, isto é, superiores aos padrões, com potencial para serem cultivados no Estado do Paraná, demonstrando a validade da metodologia usada no processo de seleção de variedades de cana-de-açúcar RB.
\end{abstract}

\begin{abstract}
Experiments were done with genotypes of sugarcane of the series RB84, RB85 and RB89, in 17 places of the State of Paraná, that is bordering area because the climatic characteristics, to the South, for the cultivation of the sugarcane. The appraised experiments are of the Experimental Phase (FE) of the process of obtaining new varieties of the Programa Cana-de-açúcar of RIDESA - PR. With the objective of validating the method used in the evaluation of new sugar-cane genotype, they were identified those with good production potential, appraised the adaptability and stability of them and compared with the series three RB. For the adaptability and stability was used the method of Eberhat and Russel and the identification and comparison of the genotype was made by test of averages, coefficient of variation among the averages of the different places, superiority frequency from the patterns, as well as histograms for frequency strip for each series. It was used the

characteristics of TCH (tons of sugar-cane culm by hectare) and TPH (tons of POL for hectare) as indicative for the choice of the best genotype. For the used method, it is possible the identification of superior genotype in the three series. The heterogeneity of the results exhibit the need of the evaluation to be done in the largest number of possible locality. The interaction of the genotype with the ambient presents production increase with the ambient improvement, with different intensity among them, by the variation in the response of the genotype to this interaction. When compared the three series, although some genotype of different series have the same progenitors, they show different behavior and for RB89 presented medium values of TCH and smaller TPH, even so, as the other series possesses promising genotype, that is superiors to the patterns, with cultivation potential in the Stale of Paraná, demonstrating the validity of the methodology used in its improvement.
\end{abstract}

